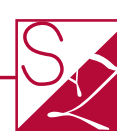

\title{
De los Ortegas buenos: Un códice en la piel de la memoria
}

Recibido: 20 de octubre / Aprobado: 29 de noviembre 2013

Anastasio Lovo*

$\mathrm{O}$ rlando Ortega Reyes (San Marcos, Carazo 1948) con esta obra "De los Ortegas buenos", por la belleza de su prosa y lo magistral del relato, sitúa la calidad del libro de crónicas y memorias en Nicaragua, en un lugar preeminente. Este libro se lee con fruición y placer. He gozado cada frase, cada párrafo, siguiendo la madeja de las anécdotas relatadas con una prosa económica, limpia, transparente, pero diseñada cerebralmente en el eje de los sintagmas como un implacable mecanismo de engranajes que dejan al lector con apetito por leer más. En estos textos todo cae por su propio peso en la más absoluta levedad del ser-escritura magistral y bella.

Hay una pasmosa solidez en la verosimilitud de lo relatado en "De los Ortegas buenos", que merece una exploración comparativa con otro amo de la escritura como es el Maestro Jorge Luis Borges. Borges diseñó y enseñó todo un tinglado de recursos y trucos para hacernos tragar a los lectores, las historias más fantásticas e imposibles. Ortega Reyes al contrario de Borges, no precisa de este trucaje para hacer gala de una propiedad objetiva en el conocimiento de los eventos, acontecimientos, hechos, ambientes, paisajes y personajes relatados, cosa que realmente asombra y le impide al lector poner en duda lo afirmado.

Aunque los hechos y personajes convertidos en relatos por Ortega Reyes, están en las antípodas de lo fantástico verosímil realizado por JL Borges, ya que todos ellos tienen una poderosa raíz en lo

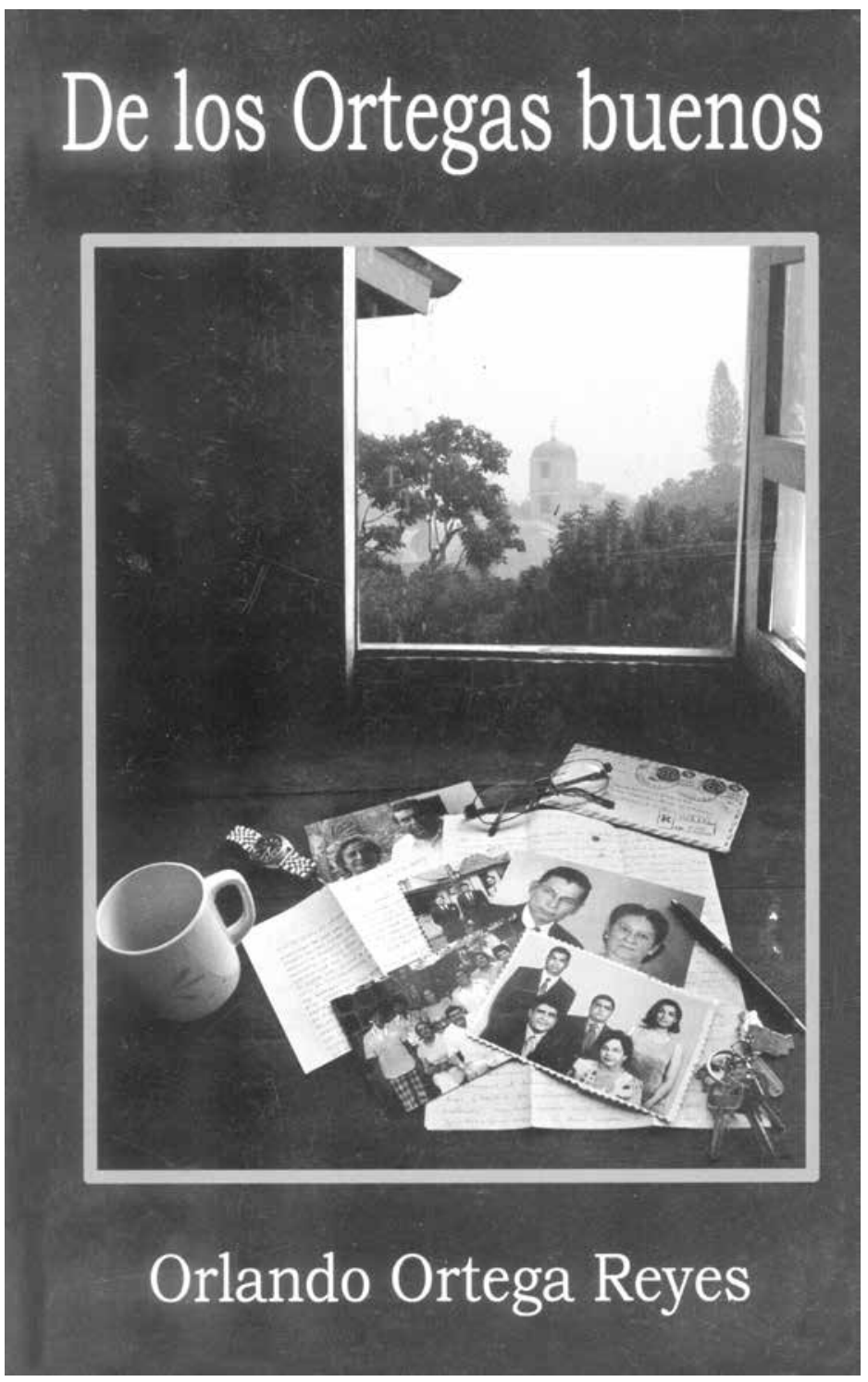

* Crítico de arte nicaragüense, Presidente del Centro Nicaragüense de Escritores (CNE), Coordinador del Área de Cultura de Paz del Instituto -"Martin Luther King" -UPOLI. 


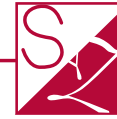

real cotidiano. Como nos percatamos al leer esta obra, lo contado por Ortega, está fundamentado en hechos, ambientes y actantes de la cotidianeidad del Pacífico de Nicaragua y abarcan un arco de tiempo que va desde la década de los años 50 del siglo XX al tiempo actual, con sus posibles regresiones y progresiones temporales más allá o acá de los años 50 .

Ortega Reyes logra en estos textos un equilibrio magistral para dotar al relato de una propiedad cabal y penetrante en el conocimiento de los hechos. En muchos de los relatos, Orlando Ortega es si no el protagonista, un testigo factual de eventos dados en el seno familiar, en la villa de San Marcos, en la ciudad de Managua y en otros ambientes urbanos nicaragüenses. Relatar lo cotidiano y lo vivido es la tarea más ardua de un cronista, cuentista, novelista o relator. Si bien la proximidad de la materia a relatar lo distancia de Borges, que saca sus historias de los anaqueles de la Biblioteca de Babel, el logro y la potencia del bien contar los aproxima.

Pero además de la seductora fuerza del conocimiento cabal de lo relatado, hay en la visión de Ortega, una sucesión de poderosas lentes epistémicas, que en un juego caleidoscópico van desmenuzando científicamente las anécdotas con sus ambientes, atmósferas y personajes. Podemos ver al relator Ortega usando de la manera más natural cosa que su sapiencia y sensibilidad le otorgan- la óptica del cronista, la del historiador, la del sociólogo, la del antropólogo, la del musicólogo, la del actor (con sus mil máscaras), las del deportista, etc. Para constituir a un hombre de letras, un ser de escritura, que logra sus relatos con belleza, precisión y efectividad.
Estos textos intitulados "De los Ortegas buenos", garantizan al lector la recuperación de tiempos y espacios perdidos por el deterioro de los materiales en el espacio externo y por el de las neuronas en el espacio anatómico interno. Pero estos relatos no se bañan en una piscina absolutamente aséptica. Una fina ironía digna de Sócrates, va tejiendo un contrapunto y una visión sesgada por el humor, que trae los eventos pasados recreados por la memoria, bajo la luz de un humor irónico finísimo que los actualiza en el escenario de la incertidumbre y el desastre contemporáneos.

Esto da lugar a saturar otro nivel abriendo un juego de relativizaciones temporales entre lo actual y lo pasado. El pasado se deconstruye con lo actual y lo actual se relativiza con lo pasado. Este juego de espejos pespunteados por la luz de la ironía, provoca sabrosos y perversos deleites al lector quien no tiene más alternativas que sonreír o prorrumpir en sonoras carcajadas.

La multiplicidad de visiones y recursos estilísticos -que estructuran la calidad de sus relatos- hacen de Orlando Ortega Reyes, un portentoso hombre de letras que nos dona una escritura perfectamente susceptible de inscribirse, grabarse o pintarse como un códice maya precolombino en la piel de la memoria.

Este libro: De los Ortega buenos merece al acucioso lector, al apasionado por los vericuetos de la memoria, a los amenazados por el alzheimer y a todos los que creemos que todo tiempo pasado fue mejor siempre que no consideremos al porvenir. Por lo pronto, ocupadísimo lector- te invito a leer estos textos para que ganen un lugar en tu corazón, en tu memoria y en tu biblioteca. 